\title{
REDISCOVERY LIBRARY SERVICE QUALITY IN STRENGTHENING QUALITY EDUCATION MANAGEMENT
}

\author{
Rorim Panday \\ Economics Faculty, Bhayangkara Jaya University, Indonesia, Jakarta \\ Email: indripan@gmail.com
}

\begin{abstract}
The library is one of the facilities to support teaching learning in college. This research was conducted at library of Bhayangkara Jaya University. The purpose of this study to reveal back of the library service quality, because the library as part of the strengthening of the quality of education management. Data were collected by a questionnaire using a Likert scale, which developed from SERVQUAL which consists of five components: tangible consists of eight variables, reliability consisting of five variables, responsiveness consisting of four variables, Assurance consist of four variables and Empathy consisting of five variables, with the number of all there are 26 variables. The data got includes service quality data and level of importance service quality from the user, the number of respondents as many as 135 peoples from library users, taken at random. Data analysis using Cartesian diagram of Importance Performance Analysis (IPA), between the importance of the service quality and the existing of services quality. The Xaxis of the Cartesian diagram is the average value of the quality of service, while its $\mathrm{Y}$ axis is the average value of the importance of the service quality. The analysis shows there are three variables that are main priorities in quadrant $\mathrm{A}$; in quadrant $\mathrm{B}$ there are seven variables that must be maintained the services quality; in Quadrant $C$ there are 11 variables into a low priority; and in quadrant $\mathrm{D}$ there are five variables that indicate less important but quality of service is good.
\end{abstract}

Keywords: Service Quality, Level of Important of Service Quality, Cartesius Diagram of IPA

\section{Introduction}

The library is one of the facilities to support the teaching-learning process in college. The library as part of the strengthening of the quality of education management. Therefore, as far as possible the library can provide satisfactory services to students in particular, and society in general, the existence of reference books needed and other reading materials. A good library certainly have a cozy reading room and quiet, so that library users can read and learn in the room. The staff serving library users are also part of the service which provides services to library users to meet users' needs. Surely friendliness, dexterity, accuracy, speed and attention to users greatly affect the quality of library services. Completeness library with e-library that is connected with a variety of other e-library will constitute an added value to the quality of library services. Bhayangkara Jaya University Library located on the campus-2 Bekasi, located in a new building, equipped with air conditioning, a reading room and study room for students or anyone who uses the library. Nevertheless, the visit rate per day is small compared to the number of students of Bhayangkara university nearing 6,000 students. Nevertheless, it will be examined the quality of service which has been running in terms of the model SERVQUAL, in order to improve the quality of library services.

\section{Review Literature}

Customer satisfaction has become an essential factor for business activity. In Marketing Management book written by Kotler (2003) assert that customer satisfaction is the level of one's feelings after comparing the performance which he felt compared with expectations. 
In addition, the definition based on the disconfirmation paradigm (Oliver, 1997), that customer satisfaction is defined as post-purchase evaluation. If the perception of the performance can not meet the expectations, there will be dissatisfaction. Meanwhile, Craig- Less (1998, in Tjiptono, 2005), an understanding of consumer behavior in the context of dissatisfaction is much deeper than in the context of customer satisfaction.

Parasuraman, Zeithaml, and Berry in the series of their research on six services company $(1985,1988,1991,1994)$ showed that the differences between consumer expectations regarding the performance of companies and consumers about the actual performance assessment provides a consumer perception of service quality. In the context of variable measurement of service quality, Parasuraman, Zeithaml and Berry (1988) grouping of five dimensions measuring service quality is reliability responsiveness assurance, tangibles, and empathy. This measurement is known as a model of service quality (SERVQUAL). Parasuraman et al. (1985, 1988). describes the development of multiple item scale to measure customer expectations and perceptions, as well as the gap between the second and the main dimensions of service quality. Research conducted on the four types of companies, ie financial institutions (Bank), credit card company, the company repairs and maintenance, as well as telephone companies, using 22 variables related to the service and then analyzed using factor analysis. Results included 10 potential complementary dimensions are tangibles, reliability, responsiveness, communication, credibility, security, competence, courtesy, understanding and access. These dimensions are then processed again until finally simplified into five dimensions: tangibles, reliability, responsiveness, assurance and empathy. As for determining the quality of service, use models $\mathrm{Q}=\mathrm{P}-\mathrm{E}$, where $\mathrm{P}$ and $\mathrm{E}$ are the perceptions and expectations of the customer care services.

Dabholkar, et al. (1996) proposed the size dimensions of service quality in retail business which includes physical aspects, reliability, personal interaction, problem solving and policy which is a combination of retail and SERVQUAL literature.

Cronin et al (1992), the research aims to test and develop methods of measuring the quality of service as well as to determine the relationship between service quality, customer satisfaction and intensity of purchase. This research was carried out on the banking company, pest control, cleaning and fast food by using 22 items of questions included in the five dimensions of service proposed by Parasuraman 1988. The analysis tool used is the analysis of factors and forwarded by using path analysis. These results indicate that the quality of service is the foundation of customer satisfaction and customer satisfaction has a greater influence on the intensity of the purchase of the quality of service.

Taylor et.al (1994), the research aims to determine the effect of customer satisfaction with the intensity of the purchase. By using regression analysis, this research shows that customer satisfaction in three industries (services parking garden, aviation transport services, long-distance telecommunications services) influence on the intensity of the purchase. But customer satisfaction not affect the intensity of the purchase of health care services.

John A. Martilla and John C. James (1977), have the purpose of the study was to measure the level of satisfaction or quality of service a service industry based on customer perception. The analysis resulted in a model that is Importance Performance Analysis or analysis of the level of importance and performance / quality of service. It also generates 
Cartesian diagram to see the layout of the elements of the implementation of the factors or attributes that affect customer satisfaction the company.

Santoso and Astuti (2003), in their study, aiming to analyze the quality of service to achieve the satisfaction of the BMT treasures. Five major dimensions of service quality are translated into each 22 attribute to expectations and performance. In addition to using the model SERVQUAL also using Importance Performance Analysis Model. Their research found that the satisfaction level of 84.4 given is between 80-100 means high satisfaction.

In the model SERVQUAL, service quality is defined as "a judgment or global attitudes regarding the superiority of merit" (Parasuraman et al, 1985), whereas the definition of quality of service which is often referred to as quality of service (Parasuraman et al, 1988) is how far the difference between reality and expectations of the customers with the services they received or acquired. Hope is the desire of the customers of the service may be provided by the company.

\section{Important Performance Analysis (IPA)}

IPA has been widely used in various studies to analyze customer satisfaction or the satisfaction of service between the quality of service received by the level of importance of the quality of service expected.The use of IPA has been implemented by:

- Adri.A.Putra (2013) in research on Urban Transportation System Performance Analysis Public Transport Area

- Simha R. Magal and Nancy M. Levenberg (2005) in their study of Using Importance-Performance Analysis to Evaluate E-Business Strategies Among Small Businesses

- Sakti Adji Adisasmita (2012) in his study of "Passanger Perception on Airport Terminal Facilities Performance" (Case Study: Soekarno-Hatta International Airport, Indonesia)

- I Nyoman Nurcaya (2007) in his research on "Analysis of Quality of Hospital Services in the province of Bali"

- Sri Hadiati, Sarwi Ruci (1999), in their study of "Performance Analysis Service Quality Customer Satisfaction at Telkomsel Malang Area"

- Zul Irmaini and Sugiarto(Januari,2016) in research on "Importance-Performance Analysis Applications In Assessing the Quality of Service Card Ak.1 At the Department of Manpower and Transmigration Cilacap".

- Herni Justiana Astuti (Januari,2016) in research of "Customer Satisfaction Analysis" (SERVQUAL Model and Important Performance Analysis Model)

- Jianwen Chen et al (2010) in research on "An Application of ImportancePerformance Analysis to Recreational Storm Chasing"

All of the above studies have used servqual and IPA models to analyze the quality of services related to customer satisfaction at different research objects. In this paper, the research conducted also using the principles servqual and IPA Cartesian diagram as a tool to analyze.

\section{Methodology}

This research is a quantitative study using a modified SERVQUAL concept, adapted to the circumstances of library studied. The questionnaire was made of two kinds, namely on the 
importance of the quality of service expected and the quality of existing services. Ratings for the quality level of service that is expected to use gradation as follows:

$1=$ Strongly disagree

$2=$ disagree

$3=$ agree

$4=$ Strongly agree

$5=$ strongly agree at all

Assessment of quality of service using the gradation as follows:

$1=$ Worst

$2=\mathrm{Bad}$

$3=$ Enough

$4=$ Good

$5=$ Very good

SERVQUAL variables that have been adjusted as follows:

Table-1. Item of Questionnaires

\begin{tabular}{|c|c|}
\hline No & Questionnaires Items \\
\hline & Tangible \\
\hline 1 & The library has modern equipment \\
\hline 2 & The physical facilities are visually appealing and comfortable \\
\hline 3 & Library employees look tidy \\
\hline 4 & Equipment associated with the service, visually appealing \\
\hline 5 & Library is equipped with a computerized database system \\
\hline 6 & Library is equipped with a cooling system (AC) \\
\hline 7 & Pleasant reading room \\
\hline \multirow[t]{2}{*}{8} & Libraries include e-library \\
\hline & Reliability \\
\hline 9 & When the library promises to do something by a certain time, he did it \\
\hline 10 & When a visitor has a problem, the library showed a genuine interest in solving it \\
\hline 11 & Libraries do service right the first time \\
\hline 12 & The service is provided on the library promises to do \\
\hline \multirow[t]{2}{*}{13} & Note that is free from error \\
\hline & Responsiveness \\
\hline 14 & Employees tell visitors when the service will be performed \\
\hline 15 & Employees provide fast service to visitors \\
\hline 16 & Employees are willing to assist visitors \\
\hline \multirow[t]{2}{*}{17} & Employees are never too busy to respond to the demand of visitors \\
\hline & Assurance \\
\hline 18 & Employee behavior instills confidence visitors \\
\hline 19 & Visitors feel safe and comfortable in the library \\
\hline 20 & Employees consistently polite \\
\hline \multirow[t]{2}{*}{21} & Employees have the knowledge to answer visitors' questions \\
\hline & Empathy \\
\hline 22 & Libraries provide individual attention for visitors \\
\hline 23 & Employees give personal attention to visitors \\
\hline 24 & Libraries understand the specific needs of visitors \\
\hline 25 & Libraries understand the interests of visitors by the heart \\
\hline 26 & Operating hours convenient to all visitors \\
\hline
\end{tabular}

Questionnaires were distributed to the respondents who have used the library, randomly and generated 135 respondents. After the data collected, do tabulation and calculated using SPSS ver 11.5, and excel. 


\section{Result and Discussion}

This study, conducted in October 2015, using questionnaires as collecting the primary data. From the data collected from respondents consisting of faculty, students, and visitors to the library as much as 135 peoples, further testing the validity and reliability, to see how the level of trust and reliability of the data obtained using questionnaires. Testing the validity and reliability using the Pearson correlation coefficient and cronbach coefficient. The results of these tests, can be seen in table- 1 . In Table 1, Pearson correlation values for each variable is significant at the 0.01 level. Thus the data obtained from the questionnaire is valid. Cronbach's value, the value is greater than 0.5 , thus the results of the questionnaire is reliable.

Table-2. Validity and Reliability test

\begin{tabular}{|c|c|c|c|}
\hline \multicolumn{4}{|c|}{ Tangible } \\
\hline \multicolumn{2}{|c|}{$\begin{array}{l}\text { Levelof importance } \\
\text { Service Quality }\end{array}$} & \multicolumn{2}{|c|}{ Service Quality } \\
\hline & $\begin{array}{c}\text { Pearson } \\
\text { Correlation }\end{array}$ & & $\begin{array}{c}\text { Pearson } \\
\text { Correlation }\end{array}$ \\
\hline E1 &, $431(* *)$ & $\mathrm{P} 1$ &, $579(* *)$ \\
\hline E2 &, $566(* *)$ & $\mathrm{P} 2$ &, $527(* *)$ \\
\hline E3 &, $545(* *)$ & P3 &, $516(* *)$ \\
\hline E4 &, $539(* *)$ & $\mathrm{P} 4$ &, $638(* *)$ \\
\hline E5 &, $436(* *)$ & P5 &, $674(* *)$ \\
\hline E6 &, $580(* *)$ & P6 &, $502(* *)$ \\
\hline E7 &, $664(* *)$ & $\mathrm{P} 7$ &, $530(* *)$ \\
\hline E8 &, $659(* *)$ & P8 &, $533(* *)$ \\
\hline Alpha & ,6702 & Alpha & ,6906 \\
\hline \multicolumn{4}{|c|}{ Reliability } \\
\hline \multicolumn{2}{|c|}{$\begin{array}{c}\text { Levelof importance } \\
\text { Service Quality }\end{array}$} & \multicolumn{2}{|c|}{ Service Quality } \\
\hline & $\begin{array}{l}\text { Pearson } \\
\text { Correlation }\end{array}$ & & $\begin{array}{c}\text { Pearson } \\
\text { Correlation }\end{array}$ \\
\hline E9 &, $624(* *)$ & P9 &, $565(* *)$ \\
\hline E10 &, $717(* *)$ & $\mathrm{P} 10$ &, $798(* *)$ \\
\hline E11 &, $772(* *)$ & P11 &, $779(* *)$ \\
\hline E12 &, $769(* *)$ & P12 &, $772(* *)$ \\
\hline E13 &, $762(* *)$ & P13 &, $699(* *)$ \\
\hline Alpha &, 7788 & Alpha & ,7681 \\
\hline \multicolumn{4}{|c|}{ Responsiveness } \\
\hline \multicolumn{2}{|c|}{$\begin{array}{c}\text { Levelof importance } \\
\text { Service Quality }\end{array}$} & \multicolumn{2}{|c|}{ Service Quality } \\
\hline & $\begin{array}{c}\text { Pearson } \\
\text { Correlation } \\
\end{array}$ & & $\begin{array}{c}\text { Pearson } \\
\text { Correlation }\end{array}$ \\
\hline E14 &, $641(* *)$ & P14 &, $540(* *)$ \\
\hline E15 & ,686(**) & P15 &, $660(* *)$ \\
\hline E16 &, $815(* *)$ & P16 &, $782(* *)$ \\
\hline E17 &, $766(* *)$ & P17 &, $693(* *)$ \\
\hline Alpha & ,6974 & Alpha &, 5704 \\
\hline \multicolumn{4}{|c|}{ Assurance } \\
\hline \multicolumn{2}{|c|}{$\begin{array}{c}\text { Levelof importance } \\
\text { Service Quality }\end{array}$} & \multicolumn{2}{|c|}{ Service Quality } \\
\hline & $\begin{array}{l}\text { Pearson } \\
\text { Correlation } \\
\end{array}$ & & $\begin{array}{l}\text { Pearson } \\
\text { Correlation }\end{array}$ \\
\hline E18 &, $745(* *)$ & $\mathrm{P} 18$ &, $684(* *)$ \\
\hline
\end{tabular}




\begin{tabular}{|c|c|c|c|}
\hline E19 &, $781(* *)$ & P19 &, $783(* *)$ \\
\hline E20 &, $834(* *)$ & P20 &, $859(* *)$ \\
\hline E21 &, $727(* *)$ & P21 &, $765(* *)$ \\
\hline Alpha &, 7735 & Alpha & ,7732 \\
\hline \multicolumn{4}{|c|}{ Empathy } \\
\hline \multicolumn{2}{|c|}{$\begin{array}{c}\text { Levelof importance } \\
\text { Service Quality }\end{array}$} & \multicolumn{2}{|c|}{ Service Quality } \\
\hline & $\begin{array}{l}\text { Pearson } \\
\text { Correlation }\end{array}$ & & $\begin{array}{c}\text { Pearson } \\
\text { Correlation }\end{array}$ \\
\hline E22 &, $721(* *)$ & $\mathrm{P} 22$ &, $721(* *)$ \\
\hline E23 &, $738(* *)$ & $\mathrm{P} 23$ &, $679(* *)$ \\
\hline E24 &, $763(* *)$ & P24 &, $778(* *)$ \\
\hline E25 &, $749(* *)$ & $\mathrm{P} 25$ &, $774(* *)$ \\
\hline E26 & ,698(**) & P26 & ,692(**) \\
\hline Alpha &, 7833 & Alpha & ,7769 \\
\hline
\end{tabular}

Thus, the data obtained from questionnaires are valid and reliable. The average value of the importance of the quality of service, quality of service, and level of conformity, quadrant layout quality of service is in table-3.

Table-3. The average value of the importance of the quality of service, quality of service, and level of conformity, quadrant layout quality of service.

\begin{tabular}{|c|c|c|c|c|c|c|c|c|c|}
\hline No & Questionnaires Items & E-Mean & $\begin{array}{c}\text { P- } \\
\text { Mean }\end{array}$ & $\mathrm{Xr}$ & $\mathrm{Yr}$ & $\mathrm{dx}$ & dy & $\begin{array}{c}\text { level of } \\
\text { conformity }\end{array}$ & Quadrant \\
\hline & \multicolumn{9}{|c|}{ Tangible } \\
\hline 1 & $\begin{array}{l}\text { The library has } \\
\text { modern equipment }\end{array}$ & 4,12 & 4,33 & 3,92 & 3,84 & 0,20 & 0,49 & 105,10 & B \\
\hline 2 & $\begin{array}{l}\text { The physical facilities } \\
\text { are visually appealing } \\
\text { and comfortable }\end{array}$ & 3,94 & 4,28 & 3,92 & 3,84 & 0,02 & 0,44 & 108,63 & B \\
\hline 3 & $\begin{array}{l}\text { Library employees } \\
\text { look tidy }\end{array}$ & 3,9 & 4,13 & 3,92 & 3,84 & $(0,02)$ & 0,29 & 105,90 & A \\
\hline 4 & $\begin{array}{l}\text { Equipment associated } \\
\text { with the service, } \\
\text { visually appealing }\end{array}$ & 3,84 & 4,25 & 3,92 & 3,84 & $(0,08)$ & 0,41 & 110,68 & A \\
\hline 5 & $\begin{array}{l}\text { Library is equipped } \\
\text { with a computerized } \\
\text { database system }\end{array}$ & 3,99 & 4,23 & 3,92 & 3,84 & 0,07 & 0,39 & 106,02 & $\mathrm{~B}$ \\
\hline 6 & $\begin{array}{l}\text { Library is equipped } \\
\text { with a cooling system } \\
\text { (AC) }\end{array}$ & 4,04 & 4,24 & 3,92 & 3,84 & 0,12 & 0,40 & 104,95 & B \\
\hline 7 & Pleasant reading room & 4,1 & 4,24 & 3,92 & 3,84 & 0,18 & 0,40 & 103,41 & $\mathrm{~B}$ \\
\hline \multirow[t]{2}{*}{8} & $\begin{array}{l}\text { Libraries include e- } \\
\text { library }\end{array}$ & 3,76 & 4,1 & 3,92 & 3,84 & $(0,16)$ & 0,26 & 109,04 & A \\
\hline & \multicolumn{9}{|c|}{ Reliability } \\
\hline 9 & $\begin{array}{l}\text { When the library } \\
\text { promises to do } \\
\text { something by a certain } \\
\text { time, he did it }\end{array}$ & 3,87 & 3,48 & 3,92 & 3,84 & $(0,05)$ & $(0,36)$ & 89,92 & $\mathrm{C}$ \\
\hline 10 & $\begin{array}{l}\text { When a visitor has a } \\
\text { problem, the library }\end{array}$ & 3,9 & 3,62 & 3,92 & 3,84 & $(0,02)$ & $(0,22)$ & 92,82 & $\mathrm{C}$ \\
\hline
\end{tabular}




\begin{tabular}{|c|c|c|c|c|c|c|c|c|c|}
\hline & $\begin{array}{l}\text { showed a genuine } \\
\text { interest in solving it }\end{array}$ & & & & & & & & \\
\hline 11 & $\begin{array}{l}\text { Libraries do service } \\
\text { right the first time }\end{array}$ & 3,76 & 3,57 & 3,92 & 3,84 & $(0,16)$ & $(0,27)$ & 94,95 & $\mathrm{C}$ \\
\hline 12 & $\begin{array}{l}\text { The service is } \\
\text { provided on the } \\
\text { library promises to do }\end{array}$ & 3,73 & 3,62 & 3,92 & 3,84 & $(0,19)$ & $(0,22)$ & 97,05 & $\mathrm{C}$ \\
\hline 13 & $\begin{array}{l}\text { Note that is free from } \\
\text { error }\end{array}$ & 3,72 & 3,47 & 3,92 & 3,84 & $(0,20)$ & $(0,37)$ & 93,28 & $\mathrm{C}$ \\
\hline & \multicolumn{9}{|c|}{ Responsiveness } \\
\hline 14 & \begin{tabular}{lll}
\multicolumn{2}{c}{ Employees } & tell \\
visitors when the \\
service will be \\
performed
\end{tabular} & 4,02 & 3,82 & 3,92 & 3,84 & 0,10 & $(0,02)$ & 95,02 & $\mathrm{D}$ \\
\hline 15 & $\begin{array}{l}\text { Employees provide } \\
\text { fast service to visitors }\end{array}$ & 3,83 & 3,56 & 3,92 & 3,84 & $(0,09)$ & $(0,28)$ & 92,95 & $\mathrm{C}$ \\
\hline 16 & $\begin{array}{l}\text { Employees are willing } \\
\text { to assist visitors }\end{array}$ & 3,96 & 3,79 & 3,92 & 3,84 & 0,04 & $(0,05)$ & 95,71 & $\mathrm{D}$ \\
\hline 17 & $\begin{array}{l}\text { Employees are never } \\
\text { too busy to respond to } \\
\text { the demand of visitors }\end{array}$ & 3,89 & 3,75 & 3,92 & 3,84 & $(0,03)$ & $(0,09)$ & 96,40 & $\mathrm{C}$ \\
\hline & \multicolumn{9}{|c|}{ Assurance } \\
\hline 18 & $\begin{array}{lr}\text { Employee } & \text { behavior } \\
\text { instills } & \text { confidence } \\
\text { visitors } & \end{array}$ & 3,91 & 3,68 & 3,92 & 3,84 & $(0,01)$ & $(0,16)$ & 94,12 & $\mathrm{C}$ \\
\hline 19 & $\begin{array}{l}\text { Visitors feel safe and } \\
\text { comfortable in the } \\
\text { library }\end{array}$ & 3,81 & 3,67 & 3,92 & 3,84 & $(0,11)$ & $(0,17)$ & 96,33 & $\mathrm{C}$ \\
\hline 20 & $\begin{array}{l}\text { Employees } \\
\text { consistently polite }\end{array}$ & 3,83 & 3,57 & 3,92 & 3,84 & $(0,09)$ & $(0,27)$ & 93,21 & $\mathrm{C}$ \\
\hline 21 & $\begin{array}{l}\text { Employees have the } \\
\text { knowledge to answer } \\
\text { visitors' questions }\end{array}$ & 3,89 & 3,73 & 3,92 & 3,84 & $(0,03)$ & $(0,11)$ & 95,89 & $\mathrm{C}$ \\
\hline & \multicolumn{9}{|c|}{ Empathy } \\
\hline 22 & $\begin{array}{lr}\text { Libraries } & \text { provide } \\
\text { individual } & \text { attention } \\
\text { for visitors } & \end{array}$ & 3,95 & 3,64 & 3,92 & 3,84 & 0,03 & $(0,20)$ & 92,15 & $\mathrm{D}$ \\
\hline 23 & $\begin{array}{l}\text { Employees give } \\
\text { personal attention to } \\
\text { visitors }\end{array}$ & 4,08 & 3,87 & 3,92 & 3,84 & 0,16 & 0,03 & 94,85 & B \\
\hline 24 & $\begin{array}{l}\text { Libraries understand } \\
\text { the specific needs of } \\
\text { visitors }\end{array}$ & 4,1 & 3,85 & 3,92 & 3,84 & 0,18 & 0,01 & 93,90 & B \\
\hline 25 & $\begin{array}{l}\text { Libraries understand } \\
\text { the interests of visitors } \\
\text { by the heart }\end{array}$ & 3,94 & 3,73 & 3,92 & 3,84 & 0,02 & $(0,11)$ & 94,67 & D \\
\hline 26 & $\begin{array}{l}\text { Operating hours } \\
\text { convenient to all } \\
\text { visitors }\end{array}$ & 3,95 & 3,67 & 3,92 & 3,84 & 0,03 & $(0,17)$ & 92,91 & D \\
\hline
\end{tabular}


In Table 3, look for tangible variable group, the level of conformity of the quality of services is already greater than $100 \%$, meaning the quality of service on tangible variable group, already in excess of the importance of the quality of service expected. For groups of variables, namely the quality of other services Reliability, Responsiveness, Assurance and Empathy, the level of compliance of the quality of its services to the level of importance of service quality is still smaller than 100; this means the quality of the service still does not meet the expected levels of service quality. To do strategies for each variable, then conducted further analysis using the quadrant method between the importance of quality of service and quality of service as shown in Figure-1.

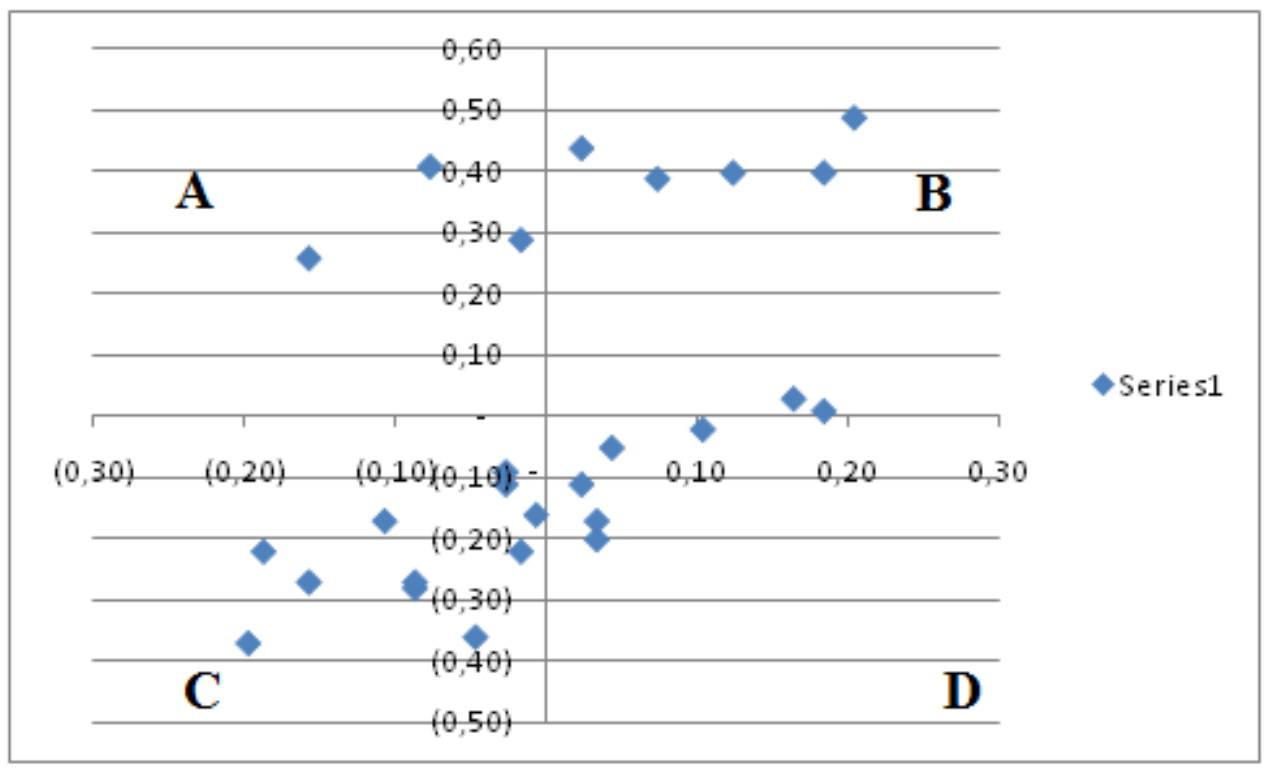

Figure-1 Cartesius Diagram of library service quality

The analysis shows there are three variables that are main priorities in quadrant A, namely X3(Library employees look tidy), X4(Equipment associated with the service, visually appealing) and X8 (Libraries include e-library); in quadrant B there are seven variables that must be maintained the quality of service that are X1(The library has modern equipment), X2(The physical facilities are visually appealing and comfortable), $\mathrm{X} 5$ (Library is equipped with a computerized database system), X6 (Library is equipped with a cooling system (AC)), X7(Pleasant reading room), X23(Employees give personal attention to visitors), and X24(Libraries understand the specific needs of visitors); in Quadrant C there are 11 variables into a low priority, namely X9(When the library promises to do something by a certain time, he did it), X10 (When a visitor has a problem, the library showed a genuine interest in solving it), X11 (Libraries do service right the first time), X12 (The service is provided on the library promises to do), X13 (Note that is free from error), X15 (Employees provide fast service to visitors), X17 (Employees are never too busy to respond to the demand of visitors), X18 (Employee behavior instills confidence visitors), X19 (Visitors feel safe and comfortable in the library), X20 (Employees consistently polite) and X21 (Employees have the knowledge to answer visitors' questions); and in quadrant $\mathrm{D}$ there are five variables that indicate less important but quality of service is good those are :X14 (Employees tell visitors when the service will be performed), X16 (Employees are willing to assist visitors), X22 (Libraries provide 
individual attention for visitors), X25 (Libraries understand the interests of visitors by the heart) and X26 (Operating hours convenient to all visitors). Thus the variables that are in quadrant $\mathrm{A}$ there are three variables that a main priority, the variables that exist in the $\mathrm{B}$ quadrant there are seven variables that must be maintained, variables that exist in the quadrant $\mathrm{C}$ there are 11 variables with low priority and variables that are in quadrant $\mathrm{D}$ there are five variables that have been excessive.

Table-4. Strategy handling service quality variables

\begin{tabular}{|c|c|c|c|c|}
\hline No & Questionnaires Items & Suistability & $\begin{array}{l}\text { Quadr } \\
\text { ant }\end{array}$ & $\begin{array}{l}\text { The strategy of handling } \\
\text { variable of service quality }\end{array}$ \\
\hline 1 & The library has modern equipment & 105,10 & $\mathrm{~B}$ & Maintained \\
\hline 2 & $\begin{array}{l}\text { The physical facilities are visually } \\
\text { appealing and comfortable }\end{array}$ & 108,63 & $\mathrm{~B}$ & Maintained \\
\hline 3 & Library employees look tidy & 105,90 & A & Main priority \\
\hline 4 & $\begin{array}{l}\text { Equipment associated with the service, } \\
\text { visually appealing }\end{array}$ & 110,68 & A & Main priority \\
\hline 5 & $\begin{array}{l}\text { Library is equipped with a computerized } \\
\text { database system }\end{array}$ & 106,02 & $\mathrm{~B}$ & Maintained \\
\hline 6 & $\begin{array}{l}\text { Library is equipped with a cooling } \\
\text { system (AC) }\end{array}$ & 104,95 & $\mathrm{~B}$ & Maintained \\
\hline 7 & Pleasant reading room & 103,41 & $\mathrm{~B}$ & Maintained \\
\hline 8 & Libraries include e-library & 109,04 & A & Main priority \\
\hline 9 & $\begin{array}{l}\text { When the library promises to do } \\
\text { something by a certain time, he did it }\end{array}$ & 89,92 & $\mathrm{C}$ & low priority \\
\hline 10 & $\begin{array}{l}\text { When a visitor has a problem, the library } \\
\text { showed a genuine interest in solving it }\end{array}$ & 92,82 & $\mathrm{C}$ & low priority \\
\hline 11 & Libraries do service right the first time & 94,95 & $\mathrm{C}$ & low priority \\
\hline 12 & $\begin{array}{l}\text { The service is provided on the library } \\
\text { promises to do }\end{array}$ & 97,05 & $\mathrm{C}$ & low priority \\
\hline 13 & Note that is free from error & 93,28 & $\mathrm{C}$ & low priority \\
\hline 14 & $\begin{array}{l}\text { Employees tell visitors when the service } \\
\text { will be performed }\end{array}$ & 95,02 & $\mathrm{D}$ & Not required \\
\hline 15 & $\begin{array}{l}\text { Employees provide fast service to } \\
\text { visitors }\end{array}$ & 92,95 & $\mathrm{C}$ & low priority \\
\hline 16 & Employees are willing to assist visitors & 95,71 & $\mathrm{D}$ & Not required \\
\hline 17 & $\begin{array}{l}\text { Employees are never too busy to respond } \\
\text { to the demand of visitors }\end{array}$ & 96,40 & $\mathrm{C}$ & low priority \\
\hline 18 & $\begin{array}{l}\text { Employee behavior instills confidence } \\
\text { visitors }\end{array}$ & 94,12 & $\mathrm{C}$ & low priority \\
\hline 19 & $\begin{array}{l}\text { Visitors feel safe and comfortable in the } \\
\text { library }\end{array}$ & 96,33 & $\mathrm{C}$ & low priority \\
\hline 20 & Employees consistently polite & 93,21 & $\mathrm{C}$ & low priority \\
\hline 21 & $\begin{array}{l}\text { Employees have the knowledge to } \\
\text { answer visitors' questions }\end{array}$ & 95,89 & $\mathrm{C}$ & low priority \\
\hline 22 & $\begin{array}{l}\text { Libraries provide individual attention for } \\
\text { visitors }\end{array}$ & 92,15 & $\mathrm{D}$ & Not required \\
\hline 23 & $\begin{array}{l}\text { Employees give personal attention to } \\
\text { visitors }\end{array}$ & 94,85 & $\mathrm{~B}$ & Maintained \\
\hline 24 & $\begin{array}{l}\text { Libraries understand the specific needs } \\
\text { of visitors }\end{array}$ & 93,90 & $\mathrm{~B}$ & Maintained \\
\hline
\end{tabular}




\begin{tabular}{|c|l|c|c|c|}
\hline 25 & $\begin{array}{l}\text { Libraries understand the interests of } \\
\text { visitors by the heart }\end{array}$ & 94,67 & $\mathrm{D}$ & Not required \\
\hline 26 & $\begin{array}{l}\text { Operating hours convenient to all } \\
\text { visitors }\end{array}$ & 92,91 & $\mathrm{D}$ & Not required \\
\hline
\end{tabular}

\section{Conclusion}

By the analysis above, Bharangkara Jaya university has rediscovery what the university needs to improve the service at library effectively as possible, to strengthening the quality of management education. This research shows there are three variables that are main priorities in quadrant $\mathrm{A}$; in quadrant $\mathrm{B}$ there are seven variables that must be maintained the services quality; in Quadrant $\mathrm{C}$ there are 11 variables into a low priority; and in quadrant $\mathrm{D}$ there are five variables that indicate less important but quality of service is good.

\section{References}

Adris.A.Putra.(2013).Transportation System Performance Analysis Urban Area Public Transport. International Refereed Journal of Engineering and Science (IRJES) ISSN (Online) 2319-183X, (Print) 2319-1821 Volume 2, Issue 6 (June 2013), PP. 01-15 www.irjes.com

Cronin,J.J.Jr. \& Taylor, A.S. (1992). Measuring Service Quality: A Reexamination and Extension, Journal of Marketing, Vol.56, July,pp.55 -68

Dabhokar, and J.O Rentz. (1996). “A Measure of Service Quality for Retail Stores: Scale Development and Validation". Journal of The Academy of Marketing Science, Vol 24 No. 1 pp 3 - 16

Herni Justiana Astuti .(januari,2016). Analisis Kepuasan Konsumen (SERVQUAL Model dan Important Performance Analysis Model). Retrieved from: http://download.portalgaruda.org/article.php?article $=9606 \& \mathrm{val}=621$

I Nyoman Nurcaya.(2007). Analisis Kualitas Pelayanan Rumah Sakit di Provinsi Bali, Retrieved from: http://download.portalgaruda.org/article.php?article=13596 $\&$ val $=933$

Jiawen Chen at all.(2010). An Application of Importance-Performance Analysis to Recreational Storm Chasing, Proceedings of the 2010 Northeastern Recreation Research Symposium.

Kotler (2003). Marketing Management. International Edition. PrentIce Hall.

Martilla, J.A. and James, J.C. (1977), “Importance-Performance Analysis", Journal of Marketing, Vol. 41 (1), pp. 77-79.

Oliver, R. L. (1997). Satisfaction: A Behavioral Perspective on The Consumer. New York: McGraw- Hill, Inc. 
Parasuraman, A., Berry, Leonard L, and Zeithaml, Valarie A. (1985). A Conceptual Model of Service Quality and Its Implications for Future Research. Journal of Marketing, Vol;. 49 (Fall), pp. 41- 50.

Parasuraman, A., Berry, Leonard L, and Zeithaml, Valarie A. (1988). SERVQUAL: A Multiple-Item Scalefor Measuring Consumer Perceptions of Service Quality.Journal of Retailing, Vol;. 64 (Spring), pp. 12 - 40.

Parasuraman, A., Berry, Leonard L, and Zeithaml, Valarie A. (1991). "Refinement and Reassessment of The SERVQUAL Scale”. Journal of Retailing, Vol;. 67 No. 4 (Winter), pp. 420-450

Parasuraman, A., Berry, Leonard L, and Zeithaml, Valarie A. (1994). "Reassessment of Expectations as a Comparison Standar in Measurung Service Quality: Implications for Future Research,. Jou rnal of Marketing, Vol;. 58 (January), pp. 111- 124.

Sakti Adji Adisasmita.(2012). Passanger Perception on Airport Terminal Facilities Performance. (Case Study: Soekarno-Hatta International Airport, Indonesia), International Journal of Engineering \& Technology IJET-IJENS Vol: 12 No: 02

Simha R. Magal and Nancy M. Levenburg.(2005), Using Importance-Performance Analysis to Evaluate E-Business Strategies among Small Businesses, Proceedings of the 38th Hawaii International Conference on System Sciences - 2005

Santoso, Suryo B dan Astuti, Herni J. (2003). Analisis Kualitas Pelayanan Ditinjau dari Kepuasan Nasabah Pada BMT (Baitul Maal Wattamwil) Khasanah di Purwokerto. Hasil Penelitian LPPM Universitas Muhammadiyah, Purwokerto

Sri Hadiati, Sarwi Ruci .(1999). Analisis Kinerja Kualitas Pelayanan Terhadap Kepuasan Pelanggan pada Telkomsel Malang Area, urnal Manajemen dan Kewirausahaan Vol.1, No. 1, September 1999 : 56 - 64

Taylor, et al . (1994). An Assessment of the Relationship Between Service Quality and Customer Satisfaction in the Formation of Consumers' Phurchase Intention. Journal of Retailing, Vol 70, No. 2, pp:163 - 178

Tjiptono, Fandy. (2005). Pemasaran Jasa. Bayumedia Publishing, Malang Zul Irmaini dan Sugiarti(Januari,2016)Aplikasi Importance- Performance Analysis Dalam Menilai Kualitas Pelayanan Pembuatan Kartu Ak.1 Pada Dinas Tenaga Kerja dan Transmigrasi Kabupaten Cilacap. Retrieved from: http://journal.unikal.ac.id/ index.php/lppm/article/viewFile/269/205 